\author{
Beatriz FLORES-ROMERO, PhD \\ Universidad Michoacana de San Nicolás de Hidalgo, México \\ E-mail: betyf@umich.mx \\ Federico GONZÁLEZ-SANTOYO, PhD \\ Instituto Iberoamericano de Desarrollo Empresarial (INIDEM) \\ E-mail: fegosa@inidem.edu.mx
}

\title{
STUDY OF THE COMPETITIVENESS OF THE MICHOACÁN COMPANY AND VARIABLES THAT AFFECT IT: APPLICATION OF THE THEORY OF FORGOTTEN EFFECTS
}

\begin{abstract}
This research consists in discovering the existing incidents between variables that reflect direct causality, as well as those that are not evident, which are fundamental for the adequate decision making to establish a strategic plan to enhance competitiveness in the MSMEs in the state of Michoacán, Mexico. The study is performed according to the basis of Forgotten Effects Theory (FET), by Kaufmann, A. and J. Gil-Aluja (1988), Gil-Aluja (2005). The results are associated to variables not taken into consideration in the initial analysis, these are the market and size of the workforce; competitive prices and material savings; competitive prices and number of workers, defective products, size of the workforce, supplier/customer relationship; technology and promotions, hierarchical levels, supplier/client relationship; statistical quality control and supplier/client relationship; organizational architecture and competitor price, promotions, material savings; career development and intensity of competition, promotions, saving of materials; relationship with suppliers and material savings.

Keywords: competitiveness, forgotten effects, development and performance of companies, Mexico.
\end{abstract}

\section{JEL classification : M11, D22, G41.}

\section{Introduction}

This paper evaluates business development in the State of Michoacán México through the forgotten effects theory (FET) proposed by Gil-Aluja (2005) and (2004), and Kaufmann and Gil-Aluja (1988),-Luis Bassa C. (2011), (Gil- Lafuente and Luis Bassa, 2011, and Álvarez Vizcarra, 2014) por within the framework of fuzzy sets, through a set of incidents, explicit, hidden or forgotten (voluntarily or 
involuntarily) among various factors and variables that impact the self-sustained performance of Micro, Small and Medium Enterprises (MSMEs) ${ }^{1}$

This approach examines the incidence among all the events, phenomena and events that surround the company, so practically all activity is subject to some type of cause-effect incidence. Even when a good control system is in place, there is always the possibility of leaving aside or forgetting, voluntarily or involuntarily, some causal relationships that are not always explicit, obvious or visible, and that are usually not perceived directly; in particular, those incidence relations that remain hidden because they are effects on effects. Likewise, companies' the decision-making process usually needs to rely on tools, techniques and models that generate a technical basis that considers all information, objective or subjective, to identify direct and indirect causal relationships. It is common to assume that the network of incidents in the performance of companies is transmitted in a chainlinked fashion, and sometimes some stage can be omitted, voluntarily or involuntarily. And each forgetting has as a consequence side effects that are affecting the entire network of incidence relationships.

The objective of this research, based on the FET, is to discover incidents between variables that reflect not only direct causality relationships, but also those that, although not evident, exist and are sometimes fundamental for the appropriate and timely decision-making in the development of MSMEs in the state of Michoacán. To achieve this goal, it is necessary to establish the mechanisms and devices that model the fact that different causes may have effects on themselves. The failure to consider the causal relationships, hidden or indirect, can cause irreversible missteps in the process of business planning.

This investigation is organized as follows: in the next section the description of the theoretical framework and the FET methodology are presented; in section 3 an application of the FET is made to Michoacán MSMEs; in the course of section 4 the empirical results obtained are discussed; Finally, in section 5 the conclusions are presented.

\section{Methodology description}

When processes are managed, it is necessary to consider not only the direct and short-term effects of some variables over others, but those that occur indirectly through interposed elements, only susceptible to being measured in the long term. In this sense, there might be many effects generated by the estimations in the different variables involved that have not been directly taken into account. Most of the positive or negative consequences of these actions occur indirectly, sometimes with a multiplying effect of the total of the characteristic belonging function.

${ }^{1}$ Other applications for the forgotten Effects theory may be found in Manna et al. (2017) and Arroyo \& Cassú (2015). 
Study of the Competitiveness of the Michoacán Company and Variables that Affect it: Application of the Theory of Forgotten Effects

Likewise, the irruption of these systems and their elements might generate progress and new opportunities for the firms.

According to Gil-Lafuente \& Barcellos-de-Paula (2010) and Gil-Lafuente, González-Santoyo \& Flores-Romero (2015), Flores, R.B. and González, S.F. (2019) all events, phenomena and facts that surround the firms' activities are integrated into a system, so it is inferred that all the activity happening within it, is influenced by the cause and effect incidence (Rico \& Tinto, 2010). Thus, an accumulation of causes that provoke them and affect the problem solution process will appear. In this sense, the FET is useful in determining the direct and indirect, evident and hidden, cause and effect relationships.

In this incidence process, cause-effect relationships are recurrent. In consequence, these can be associated to all the activities and actions carried out in the firm since all the processes that exist in the different functional areas are carried out in a sequential way. Therefore, it is possible to omit, voluntarily or involuntary, some stage of the processes, so the incidence is associated with the idea that a set of causes (attributes) affect by promoting a set of effects that derived from those and others that can be omitted or forgotten. This concept is associated with the idea of function and it is present in all those processes in which incidences are transmitted sequentially. Hence, each oversight has consequent secondary effects that affect the entire network of incidence relationships in a quasi-combinatorial process.

This is why the concept of incidence is subjective and difficult to measure, but its incorporation in the process of analysis and problem solving in decision making allows to have a better appreciation of the causes and effects that emerge in the analysis process. The incidences are propagated in a network of sequential relationships in which many stages are obviated, originating the so-called secondgeneration effects. The FET begins by assuming that there are two sets of given elements (factors): $\quad A=\left\{a_{i} \mid i=1,2, \ldots, n\right\}$ and $\quad B=\left\{b_{j} \mid j=1,2, \ldots, m\right\}$. Considering that there is an incidence of $a_{i}$ sover $b_{j} s$, if the value of the characteristic function of belonging of the pair $(a i, b j)$ is valued in $[0,1]$. So, the degree of incidence of each $a_{i}$, on each $b_{j}$, is expressed through the function: $\mu: A X B \rightarrow[0,1]$ so that: $\forall\left(a_{i}, b_{j}\right) \in A X B ; \mu\left(a_{i}, b_{j}\right) \in[0,1]$. The set of pairs of valued elements will define the direct incidences matrix, through which the cause and effect relationships that occur with different existing graduation between the elements of $A$ (causes) and the elements of $B$ (effects) are shown, which are presented according to Gil-Lafuente AM et al. (2010), Gento et al. (1999) as the direct incidence matrix denominated of first $\operatorname{order} \underset{\sim}{M}$.

The graphical representation of the $M$ matrix is made through an associated incidence graph (network) to $\underset{\sim}{M}$. For the case in which there is an associated pair 
$\left(a_{i}, b_{j}\right)$, when the value of the belonging characteristic is zero for any of the particular cases, the reference arc does not exist (it is eliminated).

The values incorporated in the incidence matrix are provided by a panel of experts in the field, and whose estimation is made when establishing the repercussions that some elements have onto others. This is the first stage in the analysis, so that subsequent proposals can be made and allow the recovering of different levels of incidence that have not been detected or that have been forgotten in the analysis process. For this it is considered a third set of elements $C=\left\{c_{k} \mid k=1,2, \ldots, p\right\}$. This set consists of elements that act as effects of the set $B$ The new incidence matrix $N$.

The two incidence matrices $\underset{\sim}{M}$ and $\underset{\sim}{N}$ have in common the elements of set $B$. The matrix $N$ has, of course, a graph representation such that each of the arrows has a numerical value $\mu\left(a_{i}, b_{j}\right)$ that indicates the degree of incidence of $a_{i}$ on $b_{j}$. Also, there are two incidence relationships $\underset{\sim}{M}$ and $\underset{\sim}{N}$ that can be seen as fuzzy subsets of $A^{\prime} B$ and $B^{\prime} C$, respectively. The level of incidences of $A$ on $C$ is done using the mathematical operator max-min. From $\underset{\sim}{M}$ and $\underset{\sim}{N}$ it is possible to propose a new incidence relationship $\underset{\sim}{P}$ between the $A$ and $C$ elements and is defined as: $P=\underset{\sim}{M} \circ N$ Where the operation o represents the max-min composition. The composition relationship of two uncertain relationships is such that $\forall\left(a_{i}, c_{p}\right) \in A \times C$ : For this, GilAluja J. (1988) is employed, from the equation shown below known as max-min convolution, which allows to know the effects of incidence of $A$ on $C$.

$$
\mu\left(a_{i}, c_{p}\right)_{\substack{M \\ \sim}}=\underset{b_{j}}{\vee}\left(\mu_{\sim}\left(a_{i}, b_{j}\right) \wedge \mu_{\sim}\left(b_{j}, c_{p}\right)\right)
$$

Hence, the matrix $\underset{\sim}{P}$ defines the causality relationships between the elements of the first set $A$ and the elements of the third set $C$, this with the intensity or degree that involves considering the elements belonging to the set $B$.

\subsection{Relationship of direct and indirect causalities}

According to Gil-Lafuente and Barcellos-de-Paula (2010), the incidence relationships when three sets of elements have been considered, an adequate methodology is selected to know the cause and effect relationships that are hidden when a causality study is made between different elements. For so doing it starts with the existence of a direct incidence relationship. That is, an uncertain cause and effect matrix defined by two sets of elements $A=\left\{a_{i} \mid i=1,2, \ldots, n\right\}$, acting as 
Study of the Competitiveness of the Michoacán Company and Variables that Affect it: Application of the Theory of Forgotten Effects

causes and $B=\left\{b_{j} \mid j=1,2, \ldots, m\right\}$, acting as effects. The causality relationship is defined by the matrix $M$, which is of (mxn) dimension, then:

$$
[\underset{\sim}{M}]=\mu_{a_{i b_{i}}} \in[0,1] ; i=1,2, \ldots, n ; j=1,2, \ldots, m
$$

Where $\mu_{a_{i b_{i}}}$ represents the values of the characteristic belonging function of each of the elements of the matrix ${ }_{M}$. The matrix $\underset{\sim}{M}$ is formed by the estimates made for all the effects that the elements of the set $A$ exert on the elements of $B$. The closer the incidence relationship, the closer it will be to $\mathbf{1}$. And vice versa, the weaker a relationship of causality between two elements is considered to be, the closer its value will be to $\mathbf{0}$. It is important to consider that matrix $\underset{\sim}{M}$ is elaborated from the direct cause and effect relationships, the relationships that are considered to be first generation. According to Barcellos-de-Paula (2010) "from this point, one of the purposes of this FET is to obtain a new incidents matrix, which reflects not only the direct causal relationships, but those that, even not being evident, exist and are sometimes fundamental for the efficient and effective appreciation of the phenomena being studied. To accomplish the stated objective, it is required to establish devices that make it possible that different causes may have effects on themselves and, at the same time, take into account that certain effects may also cause incidences on themselves. To this end, it is necessary to construct two additional incidence relationships, which will include the possible effects derived from relating causes to each other, on the one hand, and effects between them, on the other". The two auxiliary matrices are square matrices expressed as:

$$
\begin{aligned}
& \underset{\sim}{[A]}=\mu_{a_{i a_{j}}} \in[0,1] i, j=1,2, \ldots, n \\
& \underset{\sim}{\boldsymbol{B}]}=\mu_{b_{i b_{j}}} \in[0,1] i, j=1,2, \ldots, m
\end{aligned}
$$

In the matrix $[A]$ the incidence relationships that can occur between each one of the elements and that act as causes are represented. In the matrix $[B]$ the incidence relationships that can occur between each one of the elements that act as effects are represented.

We have that $[A]$ and $[B]$ coincide on the fact that both are reflexive matrices, in other words: 
Beatriz Flores-Romero, Federico González-Santoyo

$$
\begin{aligned}
& \mu_{a_{i a_{j}}}=1 ; \forall i=1,2, \ldots, n \\
& \mu_{b_{i b_{j}}}=1 ; \forall j=1,2, \ldots, m
\end{aligned}
$$

This means, that an element, cause or effect, affects with maximum presumption on itself. It is important to mention that $[A]$ and $[B]$ do not coincide nor are symmetric matrices, for the case there is at least some pair of subscripts $(i, j)$ such that:

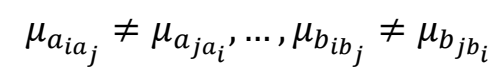

Thus, once the matrices have been built $\underset{\sim}{M},[A]$ and $[B]$, the next step is to establish the direct and indirect incidents, that is, the incidents in which, at the same time, some interposed cause or effect intervenes. From this point, the construction of the max-min composition of the reference matrices $M,[A]$ and

$[B]$ expressed as $[\underset{\sim}{A}] \circ[\underset{\sim}{\boldsymbol{M}}] \circ[\underset{\sim}{B}]=\left[{\underset{\sim}{\boldsymbol{M}}}^{*}\right]$. The established order in the

composition must allow the number of elements in the row of the first matrix to coincide with the number of elements in the column of the second matrix. The result will be a new matrix $\left[\boldsymbol{M}^{*}\right]$ which is formed by the incidents between second generation causes and effects, in other words, the initial causal relationships affected by the possible interposed incidence of some cause or some effect.

The difference between the second-generation effects matrix $\left[\boldsymbol{M}^{*}\right]$ and the direct incidents matrix $\underset{\sim}{M}$ allows to know the degree to which some causal relationships have been forgotten or obviated (forgotten effects), this can be established as $[O]=\left[M^{*}\right]-[M]$.It is also possible to know, from the degree of oversight of

some incidence, the cause-effect element that acts as a link. Because of this, the steps taken from the max-min composition of the matrices mentioned above are followed for the determination of the different paths (trajectories) in which there are forgotten effects the calculation of the previous stage is obtained with the calculation of the max-min of all the valuations established in the previous matrices for example to go from $\left(a_{i} \rightarrow b_{j}\right)$ the set of min is calculated first in each stage and then, the max of the previous set to establish which are the intermediate elements that are those that represent the forgotten incidences and their degree of valuation. 
Study of the Competitiveness of the Michoacán Company and Variables that Affect it: Application of the Theory of Forgotten Effects

In the analysis, we have that the higher the corresponding value between an element $a_{i}$ and an element $b_{j}$ of the characteristic function of belonging to the matrix $[\underset{\sim}{O}]$, the higher is the degree of oversight between $a_{i}$ and $b_{j}$ produced in the initial incidence relationship. Therefore, the implications derived from incidents that are not considered or taken into account in their true dimension, may provoke erroneous or, at least, poorly estimated actions.

\section{Case analysis in the Michoacán MSMEs}

According to Nordstrom \& Ridderstrale (2002), any firm that refuses to internationalize its operations has no chance of long-term survival in any modern economy, mainly because the international economy is exposed to a powerful process of globalization and a rapid development of information technologies. Based on the information provided by PROMEXICO (2014), among the most important characteristics that typify the MSMEs, in Mexico are that they constitute an important driver of development in the country, they have great flexibility, allowing them to increase or decrease the size of the infrastructure, as well as in changing the necessary technical processes. Due to their dynamism they have the possibility of growing and becoming a large firm, which absorb a significant portion of the economically active population, due to their great capacity to generate jobs. Likewise, they assimilate and adapt new technologies with relative ease, contribute to local, regional and national development efficiently and effectively.

According to Flores, R.B. (2007) and Flores, R.B., González, S.F., Barquero, C.D. (2015), the competitiveness for the firm is the ability to provide products and/or services efficiently and effectively to consumers regarding the competition, which allows it to position itself as a world class company, as well as generate wealth, which implies that a competitive and world-class company must offer flexibility, quality, price, continuity in offering the service, as well as having high levels of profitability. Porter, M. $(1991,1996)$ the ability of the firms to compete internationally depends on local circumstances and company strategies. According to García, S.G. (1993), the competitiveness, in principle, is the ability of the firm to incorporate a client regarding its competitors, within an open economy market. It bases its success on a continuous and lasting business relationship. The OECD (1997) defines competitiveness as a capacity of the company, industry, region or nation to generate income and high employment levels in a sustainable manner, being exposed to international competition. For the study, first, a list of selected elements was prepared to carry out the study. Afterwards, a panel of 10 experts related to the study area was selected in 2019 to evaluate the list of chosen elements, according to Kaufmann A. \& Gil-Aluja J. (1993), the evaluation was carried out taking into consideration that, $0 \leq a_{i} \leq 1,0 \leq b_{j} \leq 1$, with $i=1, \ldots, \mathrm{m} ; j=$ $1, \ldots$, n.In the study it is justified that the environmental, social and economic 


\section{Beatriz Flores-Romero, Federico González-Santoyo}

dimensions intervene in the performance of the firms. Based on the validation of the group of experts, it is considered that the set of elements $A$, which are considered external to the strict business control and that act as causes that can affect the development of the firm and its positioning in the market. The chosen elements for the analysis are presented in Table 1.

Table 1. Definition of the elements of matrix $A$

\begin{tabular}{|l|l|}
\hline $\mathrm{a}_{1}$ : Market & $\mathrm{a}_{6}:$ Quality inspection systems \\
\hline $\mathrm{a}_{2}$ : Competitive prices & $\mathrm{a}_{7}$ : Organizational architecture \\
\hline $\mathrm{a}_{3}$ : Technology & $\mathrm{a}_{8}$ : Career development \\
\hline $\mathrm{a}_{4}:$ ISO Certifications & $\mathrm{a}_{9}$ : Relationship with suppliers \\
\hline $\mathrm{a}_{5}:$ Statistical quality control & $\mathrm{a}_{10}$ : Relationship with clients \\
\hline
\end{tabular}

Source: Authors' elaboration

Based on the validation of the group of experts, the set of elements $B$ is considered, which represents the six dimensions: market, technology, managerial systems, quality, human resources, supplier/client relationship which act as effects are presented in Table 2.

Table 2. Definition of the elements of matrix $B$

\begin{tabular}{|l|l|}
\hline$b_{1}:$ Intensity of competition & $b_{8}:$ Time used in production \\
\hline$b_{2}:$ Competitor price & $b_{9}:$ Defective products \\
\hline$b_{3}:$ Market quota & $b_{10}:$ Size of the workforce \\
\hline$b_{4}:$ Promotions & $b_{11}:$ Hierarchical levels \\
\hline$b_{5}:$ Material savings & $b_{12}:$ Supplier/customer relationship \\
\hline$b_{6}:$ Number of workers & $\begin{array}{l}b_{13}: \text { Company-client product delivery } \\
\text { time }\end{array}$ \\
\hline$b_{7}:$ Quality certification & \multicolumn{1}{|l}{} \\
\hline
\end{tabular}

Source: Authors' elaboration

For the evaluation of the elements considered as cause and effect ( $\rightarrow$ b) in the firm, the experts have considered the semantic correspondence expressed in the endecadaria scale which is named for presenting 11 partitions and proving that it provides with good results in the analysis in uncertainty Gil-Aluja(1966, 1999, 2000,2004,2005) and Kaufmann \& Gil-Aluja (1988), and González, S.F., Flores, R.B., Gil, L.A. (2017) as well as the mathematical formalization of the forgotten effects, shown below in Table 3 according to Gil-Aluja (1989).

Table 3. Levels and semantic labels

\begin{tabular}{|l|l|}
\hline Level & Semantic label \\
\hline 0 & No incidence \\
\hline 0.1 & Virtually no incidence \\
\hline
\end{tabular}


Study of the Competitiveness of the Michoacán Company and Variables that Affect it: Application of the Theory of Forgotten Effects

\begin{tabular}{|l|l|}
\hline 0.2 & Almost without incidence \\
\hline 0.3 & Very weak incidence \\
\hline 0.4 & Weak incidence \\
\hline 0.5 & Medium incidence \\
\hline 0.6 & Sensitive incidence \\
\hline 0.7 & Fair amount of incidence \\
\hline 0.8 & Strong incidence \\
\hline 0.9 & Very strong incidence \\
\hline 1 & Major incidence \\
\hline
\end{tabular}

Source : Elaboration from Gil-Lafuente (1989).

In the Incidence Matrix, $M$ the cause and effect relationships are shown in different degrees that occur between the elements of the set $A$ (causes) and the elements of the set $B$ (effects). For convenience, it is expressed as $a_{i}=E_{i}$ and $b_{i}=C_{i}$.

Table 4. Matrix of estimated incidences between causes and effects $M$

\begin{tabular}{|c|c|c|c|c|c|c|c|c|c|c|c|c|c|}
\hline$C_{1}$ & 1 & 0,9 & 0,9 & 0,6 & 0,4 & 0,3 & 0,8 & 0,8 & 0,3 & 0 & 0,8 & 0,8 & 0,8 \\
\hline$C_{2}$ & 0,9 & 0,8 & 0,9 & 0,7 & 0,1 & 0 & 0,8 & 0,9 & 0,1 & 0,1 & 0 & 0 & 0,8 \\
\hline$C_{3}$ & 0,8 & 0,8 & 0,9 & 0 & 0,9 & 0,8 & 0,8 & 0,9 & 0,8 & 0,7 & 0 & 0 & 0,8 \\
\hline $\mathrm{C}_{4}$ & 0,9 & 0,8 & 0,8 & 0,1 & 0,9 & 0,9 & 0,6 & 1 & 0,9 & 0,8 & 0,6 & 0,1 & 0,7 \\
\hline$C_{5}$ & 0,6 & 0,5 & 0,7 & 0,1 & 0,8 & 0,3 & 0,9 & 0,7 & 1 & 0 & 0 & 0 & 0,8 \\
\hline $\mathrm{C}_{6}$ & 0,8 & 0,3 & 0,8 & 0,7 & 0,7 & 0,1 & 1 & 0,8 & 0,8 & 0,2 & 0,2 & 0,8 & 0,9 \\
\hline $\mathrm{C}_{7}$ & 0,1 & 0 & 0,3 & 0 & 0 & 0,9 & 0,3 & 0,5 & 0,3 & 1 & 1 & 0,2 & 0,8 \\
\hline $\mathrm{C}_{8}$ & 0 & 0,2 & 0,1 & 0 & 0 & 0,6 & 0,8 & 0,6 & 0,5 & 0,8 & 0,9 & 0,1 & 0,7 \\
\hline C & 0,8 & 0,5 & 0,8 & 0,8 & 0,1 & 0,1 & 0,4 & 0,3 & 0,2 & 0,1 & 0,2 & 1 & 0,8 \\
\hline & 0,8 & 0,6 & 0,9 & 0,8 & 0,2 & 0,5 & 0,9 & 0,2 & 0,9 & 0,1 & 0,1 & 0,9 & 0,8 \\
\hline
\end{tabular}

Source: Authors' elaboration

The initial matrix $M$ is elaborated from the opinion expressed by the 10 -expert panel and represents the relationships of direct causes and effects; that is, first generation. The objective now is to obtain an incidents matrix but that reflects not only the direct causal relationships, but also those that, although they are not evident, exist and are sometimes fundamental. To achieve this goal, it is necessary to establish the model that makes possible the fact that different causes can have 


\section{Beatriz Flores-Romero, Federico González-Santoyo}

effects on themselves and, at the same time, take into account that certain effects can also provoke incidents on themselves. For this reason, it is necessary to construct two additional incident relationships which will include the possible effects that derive from relating causes to each other, on one hand, and effects between them, on the other. In order to achieve this, the opinion of the group of experts that assesses the existing incidents between the causes is again requested, establishing a square matrix $[A]$ shown in table 5 .

Table 5. Matrix $[A]$

\begin{tabular}{|c|c|c|c|c|c|c|c|c|c|c|}
\hline$C_{1}$ & 1 & 0,9 & 0,8 & 0,8 & 0,8 & 0,8 & 0,2 & 0,1 & 0,8 & 0,8 \\
\hline $\mathbf{C}_{2}$ & 0,9 & 1 & 0,8 & 0,9 & 0,9 & 0,8 & 0,8 & 0,4 & 0,2 & 0,8 \\
\hline 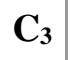 & 0,8 & 0,8 & 1 & 0,8 & 0,3 & 0,4 & 0,1 & 0,1 & 0,2 & 0,1 \\
\hline$C_{4}$ & 0,8 & 0,9 & 0,8 & 1 & 0,9 & 0,8 & 0,8 & 0 & 0 & 0 \\
\hline$\tau_{5}$ & 0,5 & 0,7 & 0,6 & 0,3 & 1 & 0,9 & 0,2 & 0 & 0,5 & 0,8 \\
\hline $\bar{C}_{6}$ & 0,5 & 0,7 & 0,5 & 0,8 & 0,8 & 1 & 0 & 0 & 0,8 & 0,6 \\
\hline 7 & 0,7 & 0,7 & 0,2 & 0,1 & 0,1 & 0,1 & 1 & 0,8 & 0,1 & 0,1 \\
\hline & 0,1 & 0 & 0 & 0,1 & 0,1 & 0,1 & 0,8 & 1 & 0,1 & 0,2 \\
\hline$C_{9}$ & 0,9 & 0,9 & 0,1 & 0,8 & 0,3 & 0,2 & 0,1 & 0,2 & 1 & 0,8 \\
\hline & 1 & 0,9 & 0,8 & 0,8 & 0,8 & 0,8 & 0 & 0 & 0,7 & 1 \\
\hline
\end{tabular}

Source: Authors' elaboration

The matrix $[B]$ is obtained with the assistance of the panel of reference experts. It expresses the incidents that exist between the effects as shown in Table 6 .

Table 6. Matrix $[B]$

\begin{tabular}{|c|c|c|c|c|c|c|c|c|c|c|c|c|c|}
\hline & 1 & 0,8 & 0,8 & 0,7 & 0,1 & 0 & 0,8 & 0,8 & 0,5 & 0 & 0 & 0,5 & \\
\hline & 0,8 & 1 & 0,9 & 0,8 & 0,9 & 0,8 & 0,8 & 0,9 & 0,8 & 0,7 & 0,4 & 0,6 & \\
\hline & 0,9 & 0,8 & 1 & 0,5 & 0,2 & 0,1 & 0,9 & 0,7 & 0,8 & 0 & of & 0,1 & \\
\hline & 0,9 & 0,8 & 0,8 & 1 & 0,2 & 0 & 0,8 & 0 & 0,8 & 0 & $\sigma$ & 0 & \\
\hline
\end{tabular}


Study of the Competitiveness of the Michoacán Company and Variables that Affect it: Application of the Theory of Forgotten Effects

\begin{tabular}{|c|c|c|c|c|c|c|c|c|c|c|c|c|c|}
\hline $\mathbf{E}_{5}$ & 0,2 & 0,8 & 0,1 & 0,7 & 1 & 0 & 0,9 & 0,8 & 0,8 & 0 & 0 & 0 & 0 \\
\hline $\mathbf{E}_{6}$ & 0,1 & 0,7 & 0,2 & 0,2 & 0,2 & 1 & 0,8 & 0,5 & 0,1 & 0,9 & 0 & 0 & 0 \\
\hline $\mathbf{E}_{7}$ & 0,7 & 0,6 & 0,8 & 0,7 & 0,8 & 0,1 & 1 & 0,8 & 0,9 & 0,7 & 0 & 0 & 0 \\
\hline $\mathbf{E}_{8}$ & 0,8 & 0,9 & 0,9 & 0,8 & 0,7 & 0,8 & 0,8 & 1 & 0,8 & 0,2 & 0,1 & 0 & 0,1 \\
\hline $\mathbf{E}_{9}$ & 0,9 & 0,2 & 0,9 & 0,8 & 0,9 & 0 & 0 & 0,5 & 1 & 0 & 0 & 0 & 0 \\
\hline $\mathbf{E}_{10}$ & 0,6 & 0,5 & 0,1 & 0 & 0 & 1 & 0,5 & 0,2 & 0,1 & 1 & 0,8 & 0,1 & 0 \\
$\mathbf{E}_{11}$ & 0,1 & 0 & 0 & 0 & 0 & 0,8 & 0 & 0 & 0 & 0,8 & 1 & 0 & 0 \\
\hline $\mathbf{E}_{12}$ & 0,2 & 0,1 & 0,8 & 0,8 & 0 & 0 & 0,5 & 0 & 0 & 0 & 0 & 1 & 0,9 \\
\hline $\mathbf{E}_{13}$ & 0,8 & 0,8 & 0,9 & 0,8 & 0,8 & 0,5 & 0,8 & 0,8 & 0,2 & 0 & 0 & 0,9 & 1 \\
\hline
\end{tabular}

Source: Authors' elaboration

Once the matrices $\underset{\sim}{M},[A]$ and $[B]$ are built, the direct and indirect incidents are established. That is, incidents in which, at the same time, some interposed cause or effect intervenes. For this, we proceed to the max-min composition of the three matrices, so that $[A] \circ[\underset{\sim}{M}] \circ\left[B_{\sim}\right]=\left[M_{\sim}^{*}\right]$. Table 7 shows the convolution matrix.

Table 7. Max-min convolution between matrices $[A] \mathbf{o}[M]$
$\begin{array}{lllllllllllllll}E_{1} & E_{2} & E_{3} & E_{4} & E_{5} & E_{6} & E_{7} & E_{8} & E_{9} & E_{10} & E_{11} & E_{12} & E_{13}\end{array}$
\begin{tabular}{l|l|l|l|l|l|l|l|l|l|l|l|l|l|}
$\mathbf{C}_{1}$ & 1 & 0,9 & 0,9 & 0,8 & 0,8 & 0,8 & 0,8 & 0,9 & 0,8 & 0,8 & 0,8 & 0,8 & 0,8 \\
\hline
\end{tabular}
\begin{tabular}{l|l|l|l|l|l|l|l|l|l|l|l|l|l|}
$\mathbf{C}_{2}$ & 0,9 & 0,9 & 0,9 & 0,8 & 0,9 & 0,9 & 0,9 & 0,9 & 0,9 & 0,8 & 0,8 & 0,8 & 0,8
\end{tabular}

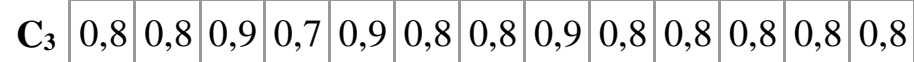
\begin{tabular}{lllllllllll|l|l|l}
$\mathbf{C}_{4}$ & 0,9 & 0,8 & 0,9 & 0,7 & 0,9 & 0,9 & 0,9 & 1 & 0,9 & 0,8 & 0,8 & 0,8 & 0,8
\end{tabular}
\begin{tabular}{l|l|l|l|l|l|l|l|l|l|l|l|l|l|}
$\mathbf{C}_{5}$ & 0,8 & 0,7 & 0,8 & 0,8 & 0,8 & 0,6 & 0,9 & 0,8 & 1 & 0,6 & 0,5 & 0,8 & 0,9
\end{tabular}
\begin{tabular}{l|l|l|l|l|l|l|l|l|l|l|l|l|l|}
$\mathbf{C}_{\mathbf{6}}$ & 0,8 & 0,8 & 0,8 & 0,8 & 0,8 & 0,8 & 1 & 0,8 & 0,8 & 0,8 & 0,6 & 0,8 & 0,9
\end{tabular}
\begin{tabular}{l|l|l|l|l|l|l|l|l|l|l|l|l|l|}
$\mathbf{C}_{7}$ & 0,7 & 0,7 & 0,7 & 0,7 & 0,4 & 0,9 & 0,8 & 0,7 & 0,5 & 1 & 1 & 0,7 & 0,8 \\
\hline
\end{tabular}
\begin{tabular}{l|l|l|l|l|l|l|l|l|l|l|l|l|l|}
$\mathbf{C}_{8}$ & 0,2 & 0,2 & 0,3 & 0,2 & 0,2 & 0,8 & 0,8 & 0,6 & 0,5 & 0,8 & 0,9 & 0,2 & 0,8
\end{tabular}
\begin{tabular}{l|l|l|l|l|l|l|l|l|l|l|l|l|l|} 
C9 & 0,9 & 0,9 & 0,9 & 0,8 & 0,8 & 0,8 & 0,8 & 0,9 & 0,8 & 0,8 & 0,8 & 1 & 0,8 \\
\hline
\end{tabular}
\begin{tabular}{l|l|l|l|l|l|l|l|l|l|l|l|l|l|}
\hline $\mathbf{C}_{10}$ & 1 & 0,9 & 0,9 & 0,8 & 0,8 & 0,8 & 0,9 & 0,9 & 0,9 & 0,8 & 0,8 & 0,9 & 0,8 \\
\hline
\end{tabular} 
Beatriz Flores-Romero, Federico González-Santoyo

\section{Source: Authors' elaboration}

The result obtained will be a new matrix $\left[M^{*}\right]$, matrix of accumulated effects, which collects the incidents between causes and effects of second generation, that is, the initial causal relationships affected by the possible interposed incidence of some cause or some effect. The table 8 shows the convolution max-min cumulative effects $[A] \mathbf{o}[M] \mathbf{o}[B]=\left[M^{*}\right]$

Table 8. Max-min convolution between matrices (Accumulated Effects)

\begin{tabular}{l|c|c|c|c|c|c|c|c|c|c|c|c|c|}
$\mathbf{2}$ & $\mathbf{E}_{1}$ & $\mathbf{E}_{2}$ & $\mathbf{E}_{3}$ & $\mathbf{E}_{\mathbf{4}}$ & $\mathbf{E}_{5}$ & $\mathbf{E}_{6}$ & $\mathbf{E}_{7}$ & $\mathbf{E}_{8}$ & $\mathbf{E}_{9}$ & $\mathbf{E}_{10}$ & $\mathbf{E}_{11}$ & $\mathbf{E}_{12}$ & $\mathbf{E}_{13}$ \\
\hline $\mathbf{C}_{1}$ & 1 & 0,9 & 0,9 & 0,8 & 0,9 & 0,8 & 0,9 & 0,9 & 0,8 & 0,8 & 0,8 & 0,8 & 0,8 \\
\hline $\mathbf{C}_{2}$ & 0,9 & 0,9 & 0,9 & 0,8 & 0,9 & 0,9 & 0,9 & 0,9 & 0,9 & 0,9 & 0,8 & 0,8 & 0,8 \\
\hline $\mathbf{C}_{3}$ & 0,9 & 0,9 & 0,9 & 0,8 & 0,9 & 0,8 & 0,9 & 0,9 & 0,8 & 0,8 & 0,8 & 0,8 & 0,8 \\
$\mathbf{C}_{4}$ & 0,9 & 0,9 & 0,9 & 0,8 & 0,9 & 0,9 & 0,9 & 1 & 0,9 & 0,9 & 0,8 & 0,8 & 0,8 \\
\hline $\mathbf{C}_{5}$ & 0,9 & 0,8 & 0,9 & 0,8 & 0,9 & 0,8 & 0,9 & 0,8 & 1 & 0,7 & 0,6 & 0,9 & 0,9 \\
$\mathbf{C}_{6}$ & 0,8 & 0,8 & 0,9 & 0,8 & 0,8 & 0,8 & 1 & 0,8 & 0,9 & 0,8 & 0,8 & 0,9 & 0,9 \\
$\mathbf{C}_{7}$ & 0,8 & 0,8 & 0,8 & 0,8 & 0,8 & 1 & 0,8 & 0,8 & 0,8 & 1 & 1 & 0,8 & 0,8 \\
\hline $\mathbf{C}_{8}$ & 0,8 & 0,8 & 0,8 & 0,8 & 0,8 & 0,8 & 0,8 & 0,8 & 0,8 & 0,8 & 0,9 & 0,8 & 0,8 \\
\hline $\mathbf{C}_{9}$ & 0,9 & 0,9 & 0,9 & 0,8 & 0,9 & 0,8 & 0,9 & 0,9 & 0,8 & 0,8 & 0,8 & 1 & 0,9 \\
$\mathbf{C}_{10}$ & 1 & 0,9 & 0,9 & 0,8 & 0,9 & 0,8 & 0,9 & 0,9 & 0,9 & 0,8 & 0,8 & 0,9 & 0,9 \\
\hline
\end{tabular}

Source: Authors' elaboration

Finally, the difference between the accumulated effects matrix and the direct incidents matrix will allow us to know the degree to which some causal relationships have been forgotten. The forgotten effects matrix will be constructed $[\boldsymbol{O}]=\left[\boldsymbol{M}^{*}\right]-[\boldsymbol{M}]$ and presented in Table 9.

Table 9. Forgotten EffectsMatrix

\begin{tabular}{|c|c|c|c|c|c|c|c|c|c|c|c|c|c|}
\hline & 0 & 0 & 0 & 0,2 & 0,5 & 0,5 & 0,1 & 0,1 & 0,5 & $\mathbf{0 , 8}$ & 0 & 0 & 0 \\
\hline & 0 & 0,1 & 0 & 0,1 & $\mathbf{0 , 8}$ & $\mathbf{0 , 9}$ & 0,1 & 0 & $\mathbf{0 , 8}$ & $\mathbf{0 , 8}$ & $\mathbf{0 , 8}$ & $\mathbf{0 , 8}$ & 0 \\
\hline & 0,1 & 0,1 & 0 & $\mathbf{0 , 8}$ & 0 & 0 & 0,1 & 0 & 0 & 0,1 & $\mathbf{0 , 8}$ & $\mathbf{0 , 8}$ & \\
\hline
\end{tabular}


Study of the Competitiveness of the Michoacán Company and Variables that Affect it: Application of the Theory of Forgotten Effects

\begin{tabular}{|c|c|c|c|c|c|c|c|c|c|c|c|c|c|}
\hline $\mathbf{C}_{4}$ & 0 & 0,1 & 0,1 & 0,7 & 0 & 0 & 0,3 & 0 & 0 & 0,1 & 0,2 & 0,7 & 0,1 \\
\hline $\mathbf{C}_{5}$ & 0,3 & 0,3 & 0,2 & 0,7 & 0,1 & 0,5 & 0 & 0,1 & 0 & 0,7 & 0,6 & $\mathbf{0 , 9}$ & 0,1 \\
\hline $\mathbf{C}_{6}$ & 0 & 0,5 & 0,1 & 0,1 & 0,1 & 0,7 & 0 & 0 & 0,1 & 0,6 & 0,6 & 0,1 & 0 \\
\hline $\mathbf{C}_{7}$ & 0,7 & $\mathbf{0 , 8}$ & 0,5 & $\mathbf{0 , 8}$ & $\mathbf{0 , 8}$ & 0,1 & 0,5 & 0,3 & 0,5 & 0 & 0 & 0,6 & 0 \\
\hline $\mathbf{C}_{8}$ & $\mathbf{0 , 8}$ & 0,6 & 0,7 & $\mathbf{0 , 8}$ & $\mathbf{0 , 8}$ & 0,2 & 0 & 0,2 & 0,3 & 0 & 0 & 0,7 & 0,1 \\
$\mathbf{C}_{9}$ & 0,1 & 0,4 & 0,1 & 0 & $\mathbf{0 , 8}$ & 0,7 & 0,5 & 0,6 & 0,6 & 0,7 & 0,6 & 0 & 0,1 \\
\cline { 2 - 13 } & 0,2 & 0,3 & 0 & 0 & 0,7 & 0,3 & 0 & 0,7 & 0 & 0,7 & 0,7 & 0 & 0,1 \\
\hline
\end{tabular}

Source: Authors' elaboration

The results are shown in bold and highlighted those significant degrees that reveal some forgotten effect, which are $\left(a_{1} \rightarrow b_{10}\right) ;\left(a_{2} \rightarrow b_{5}\right) ;\left(a_{2} \rightarrow b_{6}\right) ;\left(a_{2} \rightarrow b_{9}\right) ;\left(a_{2} \rightarrow b_{10}\right)$; $\left(a_{2} \rightarrow b_{11}\right) ;\left(a_{2} \rightarrow b_{12}\right) ;\left(a_{3} \rightarrow b_{4}\right) ;\left(a_{3} \rightarrow b_{11}\right) ;\left(a_{3} \rightarrow b_{12}\right) ;\left(a_{5} \rightarrow b_{12}\right) ;\left(a_{7} \rightarrow b_{2}\right) ;\left(a_{7} \rightarrow b_{4}\right) ;$ $\left(a_{7} \rightarrow b_{5}\right) ;\left(a_{8} \rightarrow b_{1}\right) ;\left(a_{8} \rightarrow b_{4}\right) ;\left(a_{8} \rightarrow b_{5}\right) ;\left(a_{9} \rightarrow b_{5}\right)$.

\section{Discussion of the results}

The results presented in Table 10 indicate that the cause-effect relationships that were initially valued at zero are those that have no incidence in the direct incidence matrix, at the end in the forgotten effects matrix, it is observed that there is a relationship of very strong incidence of 0.9 and 0.8 , which had been forgotten in considering a significant impact. The cause-effect relationships associated with the forgotten effects found in the work are presented in Table 10.

Table 10. Cause and effect relationships

\begin{tabular}{|l|l|}
\hline CAUSAS & EFECTOS \\
\hline Market & Size of the workforce \\
\hline Competitive prices & Material savings \\
\hline Competitive prices & Number of workers \\
\hline Competitive prices & Defective products \\
\hline Competitive prices & Size of the workforce \\
\hline Competitive prices & Supplier/customer relationship \\
\hline Technology & Promotions \\
\hline Technology & Hierarchical levels \\
\hline Technology & Supplier/customer relationship \\
\hline Statistical quality control & Supplier/customer relationship \\
\hline Organizational architecture & Competitor price \\
\hline Organizational architecture & Promotions \\
\hline
\end{tabular}


Beatriz Flores-Romero, Federico González-Santoyo

\begin{tabular}{|l|l|}
\hline \hline Organizational architecture & Material savings \\
\hline Career development & Intensity of competition \\
\hline Career development & Promotions \\
\hline Career development & Material savings \\
\hline Relationship with suppliers & Material savings \\
\hline
\end{tabular}

Source: Authors' elaboration

In order to show the results of the elements that have a greater contribution to the indirect effects, cause and effect relationships are analyzed in the forgotten effects matrix. For the analysis the values of 0.8 and 0.9 were considered for being those closest to the unit resulting:

Market and Size of the workforce $\left(a_{1} \rightarrow b_{10}\right)$ : This shows that the non-existence of commercial agreements with customers may be due to the characterization of the organizational architecture that may be of vertical type and may be necessary to transform it into an intelligent and world-class organization that has fewer hierarchical levels (jobs) and more flexible and with a smaller workforce. Therefore, with fewer resources and taking care of the elements mentioned above in the strategic plan of institutional development, the firm could improve its social responsibility and its positioning in the market by doing more business and enhancing its development with its growth. Competitive prices and Material savings $\left(\boldsymbol{a}_{2} \rightarrow \boldsymbol{b}_{5}\right)$ : The incidence $\left(a_{2} \rightarrow b_{5}\right)$ shows that, initially the panel of experts assigned an estimate of 0.1 in competitive prices and material savings, this presents incidence and relationship with number of workers, defective products, size of the workforce, hierarchical levels, relationship producers/customers and are affected by market relationships $\rightarrow$ Competitive prices $\rightarrow$ Competitor price $\rightarrow$ Defective products $\rightarrow$ Promotions, which results in a contraction of the market for MSMEs that operate in an open market, so that operational planning of processes and management associated with quality should be strengthened so that they can offer optimal products in quality at competitive prices. Competitive prices and Number of workers $\left(\boldsymbol{a}_{2} \rightarrow \boldsymbol{b}_{\mathbf{6}}\right)$ : That shows that the promotions are a fundamental factor not taken into account in the planning studies of the firm, so in considering it the production sector directs its efforts to the optimization of its process and to precise that the firm positioning does not depend on the number of workers. In this sense it depends on the determination of the minimum optimal workforce and with that being able to offer more competitive prices including the promotions.

Competitive prices and Defective products $\left(a_{2} \rightarrow b_{9}\right)$ : Thus, given that the offered products and/or services do not have or lack the quality standard demanded by the market the increase in the international commercial relations decreases the competitiveness when products showing a lower-than-demanded-by the market quality are offered. Competitive prices and Size of the workforce $\left(a_{2} \rightarrow b_{10}\right)$ : This leads to the fact that the quality certifications in the organizations motivate them to be more efficient and, in this way, they can offer a better salary level to the 
Study of the Competitiveness of the Michoacán Company and Variables that Affect it: Application of the Theory of Forgotten Effects

employees, they also strengthen the planning efforts so that the optimal workforce of the company is determined.

Competitive prices and Hierarchical levels $\left(a_{2} \rightarrow b_{11}\right)$ : This leads to the quality certifications in organizations provides elements to incorporate a functional organizational architecture that allows having an optimal staff of human resources situation that every company should take into consideration to be highly competitive. Competitive prices and Supplier/customer relationship $\left(a_{2} \rightarrow b_{12}\right)$ : This leads to technology, the incorporation in the company of quality control and inspection systems. They will allow to have highly competitive prices in the market, as well as to offer efficient and effective times to fully comply with the agreed delivery times of products to the client. Technology and Promotions $\left(\boldsymbol{a}_{3} \rightarrow \boldsymbol{b}_{4}\right)$ : This leads to the management of optimal technology, the incorporation of quality certifications and the offer of adequate prices in the market, would allow to have shorter processing times, so that the customer would be offered shorter delivery times of the product, the search for zero defective products, the establishment of excellent relations between supplier/client and being more efficient in offering prices with respect to prices handled by direct competitors. Technology and Hierarchical levels $\left(a_{3} \rightarrow b_{11}\right)$ : This leads to the incorporation of quality certifications that guide management efforts to the organizational redesign of the company and the determination of the company's optimal workforce. Technology and Supplier/customer relationship $\left(a_{3} \rightarrow b_{12}\right)$ : This leads to the incorporation of quality certifications, competitive prices, management efforts oriented to the market expansion, offering minimum delivery times of the product to the client. Statistical quality control and Supplier/customer relationship $\left(\boldsymbol{a}_{5} \rightarrow \boldsymbol{b}_{12}\right)$ : This leads to the incorporation of quality inspection systems, improving the delivery times of the product/client, strengthening the supplier relationships by virtue of efficient and effective control of the production process. Organizational architecture and Competitor price $\left(\boldsymbol{a}_{7} \rightarrow \boldsymbol{b}_{2}\right)$ : This leads to the incorporation of an optimal organizational architecture, improving product/client delivery times, offering more competitive prices for the products and/or services offered by the company. Organizational architecture and Promotions $\left(\boldsymbol{a}_{7} \rightarrow \boldsymbol{b}_{4}\right)$ : This leads to the incorporation of an optimal organizational architecture, improving the delivery times of the product/client, better product promotions to the market. Organizational architecture and Material savings $\left(\boldsymbol{a}_{7} \rightarrow \boldsymbol{b}_{5}\right)$ : This leads to the incorporation of an optimal organizational architecturecareer development, improving the delivery times of the product/client, it will be possible to improve the operation of the production system, directing the efforts to the realization of optimal production plans so that there can be savings of substantial materials. Career development and Intensity of competition $\left(a_{8} \rightarrow b_{1}\right)$ : This leads to the fact that by incorporating an organizational architecture, delivery time of the product to the client, the intensity of the competition is tended to zero. Career development and Promotions $\left(\boldsymbol{a}_{8} \rightarrow \boldsymbol{b}_{4}\right)$ : This leads to the 
incorporation of an organizational architecture, product delivery time to the client, the promotion system in the company is enhanced.

Career development and Material savings $\left(a_{8} \rightarrow b_{5}\right)$ : This leads to incorporating organizational architecture, career development; product/company client delivery time will guide the efforts to the worker is highly motivated and optimally perform their work and orient efforts to be efficient and effective, therefore as a result of the process you have savings of materials. Relationship with suppliers and Material savings $\left(a_{9} \rightarrow b_{5}\right)$ : This leads to the improvement of the organizational architecture, the delivery time of the company/client product will guide the efforts to the worker is highly motivated and optimally perform their work and orient the efforts to be efficient and effective, therefore as a consequence in the process they have savings of materials.

\section{Conclusions}

The application of the FET provides elements that classical theories do not contribute for a better study of competitiveness and the development of companies to seek to position them as world-class companies. The elements provided by this theory are not easily observable using other types of methodologies. The FET has made it possible to identify important, hidden or forgotten elements that must be considered in the design of the Strategic Development Plan of the State of Michoacán in relation to business competitiveness, and in this way incorporate strategies that allow a more efficient use of resources related to: market and size of the workforce, competitive prices and material savings, competitive prices and number of workers, competitive prices and number of workers, competitive prices and defective products, competitive prices and the size of the workforce, competitive prices and hierarchical levels, competitive prices and supplier/customer relationship, technology and promotions, technology and hierarchical levels.

\section{REFERENCES}

[1] Álvarez,Vizcarra G.(2014), Lógica borrosa, efectos olvidados y exposición al riesgo cambiario. Universidad de Occidente. México;

[2] Arroyo, E. and E. Cassú (2015), Application of the Forgotten Effects Model to the Agency Theory. Jaime Gil-Aluja, Antonio Terceño-Gómez, Joan Carles Ferrer-Comalat and José M. Merigó-Lindahl eds. Springer; Scientific Methods for the Treatment of Uncertainty in Social Sciences;

[3] Barcellos de Paula L. (2010), Modelos de gestión aplicados a la sostenibilidad empresarial. Tesis Doctoral de la Universidad de Barcelona. España;

[4] Flores, R.B, González, S.F. (2019), Factores que afectan el desempeño de las MIPYME en Michoacán, México: Un acercamiento a la teoría de los 
Study of the Competitiveness of the Michoacán Company and Variables that Affect it: Application of the Theory of Forgotten Effects

efectos olvidados. Revista Mexicana de Economía y Finanzas Nueva Época. Vol.14, No.1. pp.95-112;

[5] Flores, R.B. (2007), Los desafíos de la competitividad. La innovación organizacional y tecnológica en la empresa michoacana. Centro de Investigación y Desarrollo del Estado de Michoacán (CIDEM). Tesis Doctorado en Ciencias. Morelia México;

[6] Flores, R.B, González, S.F., Barquero, C.D. (2015), La calidad y competitividad como estrategia para el posicionamiento de la empresa. Mc. Graw Hill;

[7] García, S.C. (1993), Esquemas y modelos para la competitividad. Ediciones Castillo;

[8] Gento, A., L.L. Lazzari y E.A. Machado (1999), Reflexiones acerca de las matrices de incidencia y la recuperación de los efectos olvidados. Cuadernos del Cimbage, 4. Universidad de Buenos Aires Argentina;

[9] Gil-Aluja, J. (1996), Towards a New Paradigm of Investment Selection in Uncertainty. Fuzzy Sets and Systems, 84(3);

[10] Gil-Aluja, J. (1999), Elementos para una teoría de la decisión en la incertidumbre. Londres: Vigo Villadoiro. España;

[11] Gil-Aluja, J. (2000), Génesis de una teoría de la incertidumbre. Discurso pronunciado en ocasión del acto de imposición de la Gran Cruz de la Orden Civil de Alfonso X El Sabio, Barcelona, 20 de enero. Real Academia de Ciencias Económicas y Financieras, 27. España;

[12] Gil-Aluja, J. (2004), Aproximación metodológica a la optimización en la incertidumbre. Monográfico 2. España;

[13] Gil-Aluja, J. (2005), La matemática borrosa en la economía y gestión de empresas. SCTM-Sociedad, Ciencia, Tecnología y Matemáticas, 12. España;

[14] Gil-Lafuente A.M. y L.Barcellos-de-Paula (2010), Una aplicación de la metodología de los efectos olvidados: Los factores que contribuyen al crecimiento sostenible de la empresa. Cuadernos del CIMBAGE No. 12. FCE-UB. Argentina;

[15] Gil-Lafuente, A.M., y C. Luis Bassa (2011), Identificación de los atributos contemplados por los clientes en una estrategia CRM utilizando el modelo de efectos olvidados. Cuadernos del Cimbage, 13, 107-127;

[16] Gil-Lafuente A.M., F. González-Santoyo y B. Flores-Romero(2015), Teoría de los efectos olvidados en la incidencia de la actividad económica en la calidad de vida de los habitantes y cuantificación de los efectos para un reequilibrio territorial. INCEPTUM. Vol. X, No. 19. JulioDiciembre, pp. 105-122. Morelia, México;

[17] González, S.F., Flores, R.B., Gil, L.A. (2017), Fuzzy Logic in the Design of Public Policies: Application of Law. Economic Computation and Economic Cybernetics Studies and Research. Vol.51, No.2. pp.281-290; 
[18] Kaufmann A.y J. Gil-Aluja (1988), Modelos para la investigación de los efectos olvidados. Milladoiro. Vigo. España;

[19] Kaufmann A. y J. Gil-Aluja (1989), Models per la recerca d'efectes oblidats. Ed. Milladoiro. España;

[20] Kaufmann A. y J. Gil-Aluja (1993), Técnicas especiales para la gestión de expertos. Milladoiro. Santiago de Compostela. España;

[21] Luis Bassa C. (2011), Modelos para el análisis de atributos contemplados por los clientes en una estrategia de marketing relacional. Tesis Doctoral de la Universidad de Barcelona. España;

[22] Manna, E. M., J. Rojas-Mora and C. Mondaca-Marino (2017), Application of the Forgotten Effects Theory for Assessing the Public Policy on Air Pollution of the Commune of Valdivia, Chile. In Benô̂t Otjacques, Patrik Hitzelberger, Stefan Naumann, and Volker Wohlgemuth eds. Springer, Science to Society, pp 61-72;

[23] Nordstrom, K. and J. Ridderstrale (2002), Funky Business: Talent Makes Capital Dance. Pearson Education;

[24] OCDE (1997), Industrial Competitiveness. OCDE. París;

[25] Porter, M.E. (1991), Ventaja competitiva de las naciones. Vergara;

[26] Porter, M.E. (1999), Ser competitivo. Nuevas aportaciones y conclusiones. Deusto;

[27] PROMEXICO (2014), Negocios internacionales: PYMES Eslabón fundamental para el crecimiento de México. Recuperado de PROMEXICO:http://www.promexico.gob.mx/negociosinternacionales/pymes-eslabn-fundamental-para-el-crecimiento-enmexico.html;

[28] Rico, M. A. y J. Tinto (2010), Herramientas con base en subconjuntos borrosos. Propuesta procedimental para aplicar expertizaje y recuperar efectos olvidados en la información contable. Actualidad Contable FACES Año 13 Nº 21, Julio- Diciembre 2010. Mérida. Venezuela (127146);

[29] Secretaría de Economía (2015), Clasificación de las empresas en México. Recuperado de la Secretaría de Economía:http://www.economia.gob.mx/files/transparencia/informe APF/ memorias/28_md_cncmipyme.pdf. 